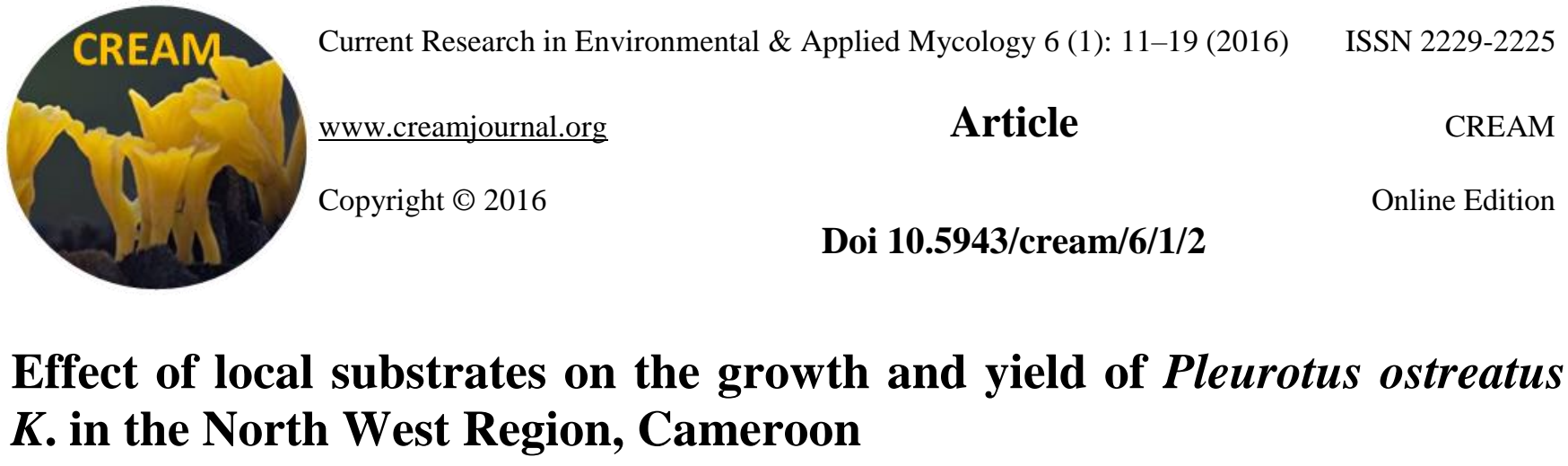

\title{
Kinge $\mathrm{TR}^{1}$, Djidjou TAM${ }^{1}, \mathrm{Nji} \mathrm{TM}^{2}$, Ache $\mathrm{NA}^{3}$ and Mih $\mathrm{AM}^{3}$
}

\author{
${ }^{1}$ Department of Biological Sciences, Faculty of Science, University of Bamenda, P. O. Box 39, North West Region, \\ Cameroon \\ ${ }^{2}$ Department of Sociology and Anthropology, Faculty of Social and Management Sciences, University of Buea, P.O. Box 63, \\ South West Region, Cameroon \\ ${ }^{3}$ Department of Botany and Plant Physiology, Faculty of Science, University of Buea, P. O. Box 63, South West Region, \\ Cameroon
}

Kinge TR, Djidjou TAM, Nji TM, Ache NA, Mih AM 2016 - Effect of local substrates on the growth and yield of Pleurotus ostreatus $K$. in the North West Region, Cameroon. Current Research in Environmental \& Applied Mycology 6(1), 11-19, Doi 10.5943/cream/6/1/2

\begin{abstract}
Food security to the ever growing world population is a major challenge of the $21^{\text {st }}$ century. Scientists all over the world are seriously exploring ways and means to bring more food on the table. Cultivation of highly nutritional and medicinal mushrooms on local substrates is one of such effort. In an attempt to bring in our own contribution, locally available substrates for the cultivation of Pleurotus ostreatus was investigated at the Mbeng-Adio mushroom cultivation center Banjah Bamenda, Cameroon from March to September 2015. Pleurotus ostreatus was cultivated on different supplemented substrates such as Corn cobs on corn flour T1, Corn cobs on rice bran T2, Iroko on corn flour T3, Iroko on rice bran T4, Eucalyptus on corn flour T5 and Eucalyptus on rice bran T6; supplemented with $1 \% \mathrm{CaCO}_{3}$. The experiment was laid in a completely randomized design. The effects of various substrates on comparative growth and yield performance of oyster mushroom were then analyzed. The highest degree of colonization after inoculation (95\%) and lowest time from primordia initiation to harvest (3.25days) were obtained in T6. The highest biological yield (0.47 $\mathrm{kg} /$ packet $)$, economic yield $(0.43 \mathrm{~kg} /$ packet $)$ and $75 \%$ contamination were obtained with $\mathrm{T} 1$. Highest fresh weight $(0.47 \mathrm{~kg} /$ packet $)$, highest dry weight $(0.09 \mathrm{~kg} /$ packet $)$, highest average number of primordia/packet(226.3), highest average number of fruiting body/packet(43.25), the highest average weight of individual fruiting body $(0.02 \mathrm{~kg})$, highest mean thickness of stipe (12.08) and the highest average number of effective fruiting body/packet(26.25) were obtained in T5. Among many aspects, T5 was found as the best substrate with biological yield $(0.47 \mathrm{~kg} /$ packet $)$ and economic yield $(0.43$ $\mathrm{kg} /$ packet) followed by $\mathrm{T} 1, \mathrm{~T} 6, \mathrm{~T} 4$, and $\mathrm{T} 3$, with $\mathrm{T} 2$ rejected due to $100 \%$ contamination for the production of the oyster mushroom.
\end{abstract}

Key words - Basidiomycetes - domestication - macrofungi - Oyster mushroom

\section{Introduction}

Mushrooms are reproductive structures of some fungi mostly the Basidiomycetes and some Ascomycetes roughly equivalent to the flowers on an apple tree, which contain the "seeds" of the future tree (Nicholas \& Kerry 2006). They have been universally recognized now as food and are increasingly 
being grown on commercial scale in many parts of the world. China which is the largest producer of various mushrooms in the world has had a $24.3 \%$ increase in production over a ten year period between 2000 to 2010 ( $\mathrm{Li}$ 2012). Cultivation is a wonderful activity as the fungi does not depend on weather conditions such as rainfall and can thus be grown all year round in cropping houses (Bonginkhosi et al. 2012). Mushrooms are appreciated for their good taste and nutritional value. The income from edible mushrooms is an important source of revenue for farmers, especially in developing countries. The increased consumer demand over the years has resulted in production of mushrooms in large proportions through cultivation which is a highly efficient method for recycling the agricultural residues so as to produce nutritious food (Atri \& Lata 2013).

Commercial production of fresh edible mushrooms is a rapidly growing industrial activity that can be carried out in a large or small scale. It is an efficient and relatively short biological process of food protein recovery from negative value lignocellulosic materials, utilizing the degrading capabilities of mushrooms (Ediriweera et al. 2015). The Oyster mushroom Pleurotus ostreatus is characterized by its rapid growth on agro-wastes such as dried sugar cane leaves, saw dust, maize stover, banana leaves, palm cones, coffee husks and wheat bran which are substrates for mushroom production (Beetz \& Kustida 2004, Lourdes et al. 2008, Ajonina \& Tatah 2012). Sawdust types differ but softwood sawdust like mango and cashew are known to be more suitable than hardwood sawdust (Pathmashini et al. 2008). These substrate materials can be supplemented with corn flour, rice bran, molasses, soya bean or kernel cake in accordance with the particular substrate material used. Even though there has been considerable research on the taxonomy and phylogeny of mushrooms, there has been far less research on their domestication (Thawthong et al. 2014).

In Cameroon, agriculture and forestry are two prominent sectors which bring in revenue to the government (Degrande et al. 2007). Unfortunately most of the resulting waste products like sawdust from timber exploitation, rice husk or maize stover, are not often recycled appropriately through their use in the cultivation of mushroom. This may be due to lack of knowledge on the use of these substrate materials in mushroom cultivation. Cameroon's food supply in most rural areas is diminishing caused by increasing environmental deterioration (Kinge et al. 2014). The consequences are malnutrition, starvation, diseases and low life expectancy of these populations. Mushroom cultivation therefore comes not only to provide an opportunity to improve the local farmers livelihoods and reduce dependence on natural farm resources, but also to provide them with mushrooms having valued medicinal properties like immunomodulatory and antitumor activities (Wang et al. 1996). The need for commercial production of this edible mushroom in the country cannot be over emphasized. Unfortunately, very few individuals are involved in mushroom cultivation. Most of the research works in Cameroon have been on the taxonomy and documentation of the diversity of macrofungi and very few on modes of cultivation (Douanla-Meli 2007, Egbe et al. 2013, Kinge et al. 2014). This study therefore aimed at investigating the effect of local substrates in the cultivation of Pleurotus ostreatus in the North West Region of Cameroon. This may subsequently help in increasing living standards, environmental cleaning, providing protein and self employment in the country.

\section{Materials \& Methods}

\section{The Study Area}

The research was conducted at Mbeng-Adio mushroom research center Banjah (Fig. 1), in Bamenda, North West Region of Cameroon from March to September 2015. The research center is located at an altitude of $1647 \mathrm{~m}$ above sea level and has the following latitude and longitude coordinates; $\mathrm{N} 05^{\circ} 57.431^{\prime}$ and $\mathrm{E} 010^{\circ} 13.093^{\prime}$ respectively. An average temperature of $21-22^{\circ} \mathrm{C}$ was found during the period of cultivation.

\section{Sterilization Procedure and Preparation of Spawns}

In the laboratory, all of the apparatus, equipment, metallic instruments, glassware and culture media were sterilized in drums at $121^{\circ} \mathrm{C}$ for about 2 hour at $1.5 \mathrm{~kg} / \mathrm{cm}$ pressure. The culture room was 
cleaned by gently washing with detergent followed by $70 \%$ ethyl alcohol regularly. All the instruments and equipment used were sterilized with alcohol before use.

The mother culture substrate was prepared by sawdust and corn flour in the ratio2:1with $0.1 \%$ calcium carbonate (Amin et al. 2007). It was mixed thoroughly with hands and moisture maintained by adding sufficient water for $65 \%$ moisture content, controlled using the hand squeezing test. Then $1000 \mathrm{~g}$ of this mixture was packed tightly in $15 \times 5 \mathrm{~cm}$ mayonnaise glass bottles. Each of the bottles was covered tightly with middle- holed covers. The holes on the covers were plugged with cotton and this served as a sterile opening through which the fungus breaths. The bottles were sterilized for 2 hour at $121^{\circ} \mathrm{C}$ with $1.5 \mathrm{~kg} / \mathrm{cm}^{2}$ pressure in drum sand after they were kept for cooling. Mushroom seeds were placed aseptically on them other spawn bottles in a sterilized glove box. The bottles after inoculation were kept at $20-22^{\circ} \mathrm{C}$ for spawn run in a dark cupboard. The whole bottle containing substrate became white due to fungal mycelia proliferation within 20-25 days, and thus ready for spawning the substrate.

Two sawdust species (Eucalyptus and iroko), were obtained from carpenter shops at Nkwen Mile 4 and each divided into two equal portions. One portion of each was supplemented with rice husk, and rice bran in the ratio $4: 2: 1$ and $0.25 \mathrm{~kg}$ of quick lime. The other portion supplemented with rice husk, corn flour and quick lime in the same ratio. The material was mixed thoroughly on a clean cemented floor using a spade. The moisture increased by adding water until it reached around $65 \%$ moisture content. Then polypropylene bags $(25 \times 18 \mathrm{~cm})$ were filled, four with $2.0 \mathrm{~kg}$ prepared substrate of each of the four prepared portions of substrate materials and packed tightly. The packets were sterilized in drums at $121^{\circ} \mathrm{C}$ for 2 hours and kept 12 hours for cooling. Three table spoonfuls of mother culture materials from mother spawn containing mycelia were placed aseptically after opening in each packet. The two differently supplemented portions of each sawdust being treatments each were replicated 4 times, giving a total of 16packets. The packets were then marked treatment wise with paper notices after tying with different coloured threads and kept on the shelves in an incubation room at $25 \pm 1{ }^{\circ} \mathrm{C}$ under $80 \%$ to $85 \%$ relative humidity and allowed to complete the whitish mycelia growth.

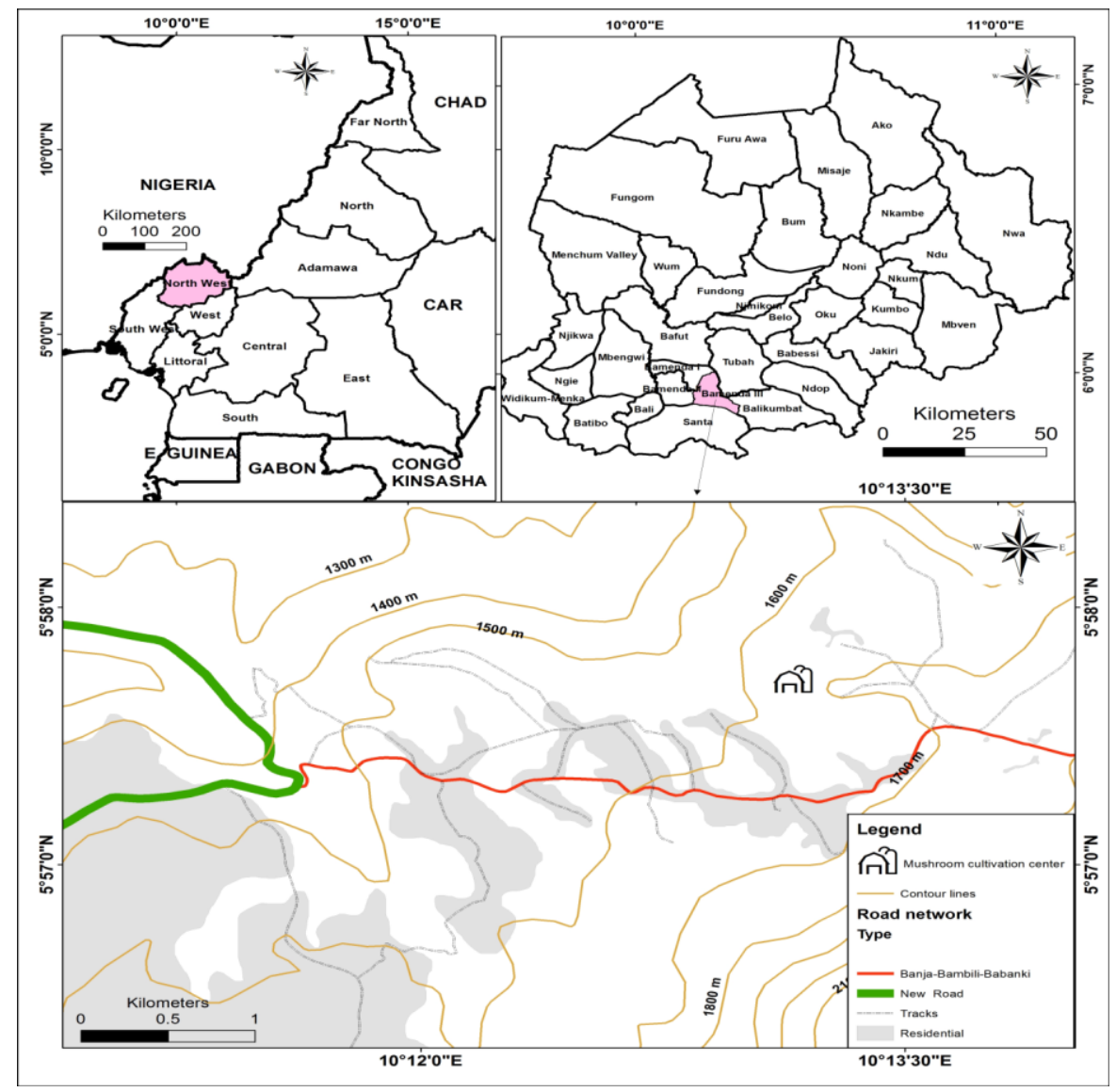

Fig. 1- Locational map of Banjah (Kinge et al. 2015) 


\section{Preparation of maize stover substrates}

The maize stover was obtained from farms in Bandjoun (West Region) and sun dried. It was divided into two portions. These two portions were supplemented each separately. One with rice bran in the ratio $4: 2$ and $0.25 \mathrm{~kg}$ of quick lime, the other portion with corn flour and quick lime in the same amounts as above. The material was mixed thoroughly on a clean cemented floor using a spade. The moisture increased by adding water until it reached around $65 \%$ moisture content. Then polypropylene bags $(25 \times 18 \mathrm{~cm})$ were filled 4 each with $2.0 \mathrm{Kg}$ of one portion of prepared substrate and packed tightly. The packets were sterilized in drums at $121^{\circ} \mathrm{C}$ for 2 hours and kept 12 hours for cooling. Three table spoonful of mother spawn were inoculated aseptically. The two differently supplemented portions were carried out in four replicates. All bags were incubated at $25 \pm 1{ }^{\circ} \mathrm{C}$ under $80-85 \%$ relative humidity until completely colonized. The experiment was laid out in a completely randomized design (CRD) with six treatments and four replications as shown on Table 1.

Table 1 Various treatments and their identification marks

\begin{tabular}{|c|c|c|}
\hline Treatments & Substrates & Composition \\
\hline $\mathrm{T} 1$ & Substrate 1 & $\begin{array}{l}\text { Eucalyptus on corn flour and } \mathrm{CaCO} 3 \text { (tied normally). In the ratio } \\
69: 30: 1 \text { respectively }\end{array}$ \\
\hline $\mathrm{T} 2$ & Substrate2 & $\begin{array}{l}\text { Eucalyptus on rice bran and } \mathrm{CaCO} 3 \text { (tied with white thread). In } \\
\text { the ratio } 69: 30: 1 \text { respectively }\end{array}$ \\
\hline $\mathrm{T} 3$ & Substrate3 & $\begin{array}{l}\text { Corn cobs on corn flour and } \mathrm{CaCO} 3 \text { (tied with orange thread). In } \\
\text { the ratio } 69: 30: 1 \text { respectively }\end{array}$ \\
\hline $\mathrm{T} 4$ & Substrate 4 & $\begin{array}{l}\text { Corn cobs on rice bran and } \mathrm{CaCO} 3 \text { (tied normally). In the ratio } \\
69: 30: 1 \text { respectively }\end{array}$ \\
\hline T5 & Substrate 5 & $\begin{array}{l}\text { Iroko on rice bran and } \mathrm{CaCO} 3 \text { (tied with yellow thread). In the } \\
\text { ratio } 69: 30: 1 \text { respectively }\end{array}$ \\
\hline T6 & Substrate 6 & $\begin{array}{l}\text { Iroko on corn flour and } \mathrm{CaCO} 3 \text { (tied with blue thread). In the } \\
\text { ratio 69:30:1 respectively }\end{array}$ \\
\hline
\end{tabular}

\section{Harvesting}

Harvesting was carried out when the fruiting bodies were matured. Harvesting was made three times for each bag of substrate. The process of harvesting involved the removal of the matured fruiting bodies from their substrate without any destruction on the substrate bag. The mature mushroom was held on their stipe below the pileus and close to the substrate level and was gradually pulled out. All fruiting bodies of a particular substrate bag were harvested at the same time since each bag had to be watered after harvest. Watering was done by immersing the bags in a bowl of water for 5 seconds. This was done to enable the substrate to have moisture that enables fruiting to occur again for harvest.

\section{Morphological Data collection}

Data was recorded on the following parameters;

Time from Stimulation to Primordia Initiation (days): Time required from stimulation to primordia initiation (days) was counted and recorded. Time from Primordial Initiation to Harvest (days): Time required from primordial initiation to harvest (days) was counted and recorded. Average Number of Primordial/Packet: Number of primordial/packet was counted and recorded. Average Number of fruiting Body/Packet: Number of well-developed fruiting body was counted and recorded. Dry and pinheaded fruiting bodies discarded but tiny fruiting bodies included in counting. Average Number of Effective Fruiting Body/Packet: Number of very well-developed fruiting body was counted and recorded. Tiny fruiting bodies discarded from counting. Average Weight of Individual Fruiting Body/Packet: Average weight of individual fruiting body was calculated by dividing the total weight of fruiting body per packet obtained from the balance reading by the total number of fruiting body per packet. Dimension of Fruiting Body (pileus and stipe): Diameter of pileus (The mushroom pileus diameter was taken from one end of the pileus to the other passing through the centre of the pileus and measured in cm using a tailor's tape), thickness of stipe (The thickness of stipe was taken at the base 
of the stipe where it attaches to the substrate from one end of the stipe base to the other passing through the centre and measured in cm using a tailor's tape) and length of stipe (This was measured in centimeters using a tailor's tape from the point where it was attached to the substrate to the point where the gills on the pileus start on the stipe). All these measurements were done on 3 randomly selected bags of fruiting bodies per treatment after harvest and then the average was calculated. Biological Efficiency was calculated as; Fresh weight of mushroom/Dry weight mushroom x 100.

\section{Data Analysis}

The data was analyzed using ANOVA and treatment means compared using Duncan's Multiple Range Test (Gomez \& Gomez 1984). The graphical representation was done using Statgraphics Centurion XV, Sigma plot 2000 and excels 2007. A correlation between economic yield and fresh weight was determined and was expressed by the equation $y=1.144 x-0.026\left(R^{2}=0.9224 * *\right)$ where $y=$ economic yield and $x=$ fresh weight of fruiting body ( Bhattacharjya et al. 2014).

\section{Results}

\section{Effect of substrates on early growth performance}

The time from stimulation to primordia initiation ranged from 20.00-27.00days. All the treatments were statistically different. The lowest time from stimulation to primordia initiation was observed in T6 (20.00 days). The highest time from stimulation to primordia initiation was observed in $\mathrm{T} 1$ (27.00days). The time from primordia initiation to harvest ranged from 3.25-5.50days. The lowest time from primordia initiation to harvest was observed in $\mathrm{T} 6$ (3.25 days).The highest time from primordia initiation to harvest was observed in $\mathrm{T} 1$ (5.50days). Statistically, similar primodia initiation to harvest was shown in T6 (3.25days), T3 (3.25days), T1 (5.50) and T5 (4.75days) treatments. There was significant difference in the number of contaminated bags. T1 (75\%) and T2 (100\%) were the only treatments contaminated. These results are shown inTable 2.

Table 2 Effect of substrates on early growth performance

\begin{tabular}{lllll}
\hline & $\begin{array}{l}\text { Stimulation to } \\
\text { primordial initiation } \\
\text { (days) }\end{array}$ & $\begin{array}{l}\text { Primordial } \\
\text { initiation to } \\
\text { harvest (days) }\end{array}$ & $\begin{array}{l}\text { Degree of } \\
\text { colonisation after } \\
\text { innoculation (\%) }\end{array}$ & $\begin{array}{l}\text { Contamination } \\
(\%)\end{array}$ \\
\hline $\begin{array}{l}\text { Corn cobs_corn flour } \\
\text { T1 }\end{array}$ & $27.00 \pm 0.00^{\mathrm{c}}$ & $5.50 \pm 0.58^{\mathrm{b}}$ & $65.00 \pm 0.00^{\mathrm{b}}$ & $75.00 \pm 50.00^{\mathrm{b}}$ \\
$\begin{array}{l}\text { Corn cobs_rice bran T2 } \\
\text { Iroko_corn flour T3 }\end{array}$ & $25.50 \pm 1.00 \mathrm{~b}^{\mathrm{c}}$ & $3.25 \pm 0.50^{\mathrm{a}}$ & $65.00 \pm 0.00^{\mathrm{b}}$ & $100.00 \pm 0.00^{\mathrm{b}}$ \\
$\begin{array}{l}\text { Iroko_rice bran T4 } \\
\text { Eucalyptus_corn flour }\end{array}$ & $24.00 \pm 2.45^{\mathrm{abc}}$ & $4.25 \pm 0.96^{\mathrm{ab}}$ & $75.00 \pm 0.00^{\mathrm{a}}$ & $00.00 \pm 0.00^{\mathrm{a}}$ \\
T5 & $22.00 \pm 4.69^{\mathrm{ab}}$ & & $75.00 \pm 0.00^{\mathrm{c}}$ & $00.00 \pm 0.00^{\mathrm{a}}$ \\
$\begin{array}{l}\text { Eucalyptus_rice } \\
\text { T6 bran }\end{array}$ & $20.25 \pm 2.63^{\mathrm{a}}$ & $4.75 \pm 0.96^{\mathrm{b}}$ & $87.00 \pm 0.00^{\mathrm{d}}$ & $00.00 \pm 0.00^{\mathrm{a}}$ \\
\hline $\mathrm{F}$ (p) & $4.04(0.02)$ & $3.25 \pm 0.96^{\mathrm{a}}$ & $95.00 \pm 0.00^{\mathrm{e}}$ & $00.00 \pm 0.00^{\mathrm{a}}$ \\
\hline
\end{tabular}

Means followed by same letter significantly different at $1 \%$ or $5 \%$ level of significance

\section{Effect of substrate on Yield Attributes of oyster mushroom}

The Mean Average number of fruiting body per packet, Mean Average number of effective fruiting body and Mean Diameter of pileus $(\mathrm{cm})$ were statistically similar for each treatment but numerically varied. The Mean thickness of stipe $(\mathrm{cm})$ was higher in T5 (12.08) and lowest in T6 (3.53). The later was statistically different from T1 (8.30) but statistically similar to T3 (4.60) and T4 (5.03). Finally, the Mean Length of stipe (cm) was highest in T1 (6.30) and lowest in T4 (4.03) as shown in Table 3. 
Table 3 Effect of substrates on yield attributes of oyster mushroom

\begin{tabular}{|c|c|c|c|c|c|}
\hline Treatments & $\begin{array}{l}\text { Mean Average } \\
\text { number of } \\
\text { fruiting body } \\
\text { per packet }\end{array}$ & $\begin{array}{l}\text { Mean Average } \\
\text { number of } \\
\text { effective } \\
\text { fruiting body }\end{array}$ & $\begin{array}{l}\text { Mean } \\
\text { Diameter of } \\
\text { pileus }(\mathbf{c m}) \\
\end{array}$ & $\begin{array}{l}\text { Mean Thickness } \\
\text { of stipe }(\mathrm{cm})\end{array}$ & $\begin{array}{l}\text { Mean Lenght } \\
\text { of stipe }(\mathrm{cm})\end{array}$ \\
\hline \multicolumn{6}{|l|}{ Corn cobs_corn flour } \\
\hline $\mathrm{T} 1$ & $42.00 \pm 0.00^{\mathrm{a}}$ & $26.00 \pm 0.00^{\mathrm{a}}$ & $8.30 \pm 0.0 .0^{\mathrm{a}}$ & $8.30 \pm 0.00^{b}$ & $6.30 \pm 0.00^{\mathrm{b}}$ \\
\hline Iroko_corn flour T3 & $34.75 \pm 11.53^{\mathrm{a}}$ & $25.00 \pm 4.69^{\mathrm{a}}$ & $8.00 \pm 1.15^{\mathrm{a}}$ & $4.60 \pm 0.69^{\mathrm{a}}$ & $4.10 \pm 0.12^{\mathrm{a}}$ \\
\hline Iroko_rice bran $\mathrm{T} 4$ & $35.75 \pm 4.57^{\mathrm{a}}$ & $19.75 \pm 3.10^{\mathrm{a}}$ & $8.30 \pm 1.13^{\mathrm{a}}$ & $5.03 \pm 0.19^{\mathrm{a}}$ & $4.03 \pm 0.19^{\mathrm{a}}$ \\
\hline \multicolumn{6}{|l|}{ Eucalyptus_corn flour } \\
\hline & $43.25 \pm 24.86^{\mathrm{a}}$ & $26.25 \pm 12.39^{\mathrm{a}}$ & $7.98 \pm 1.24^{\mathrm{a}}$ & $12.08 \pm 2.57^{\mathrm{c}}$ & $5.18 \pm 1.75^{\mathrm{ab}}$ \\
\hline Eucalyptus_rice & & & & & \\
\hline T6 & $43.00 \pm 13.49^{\mathrm{a}}$ & $23.25 \pm 5.12^{\mathrm{a}}$ & $9.48 \pm 0.99^{\mathrm{a}}$ & $3.53 \pm 1.43^{\mathrm{a}}$ & $5.73 \pm 1.95^{\mathrm{ab}}$ \\
\hline $\mathrm{F}(\mathrm{p})$ & $0.36(0.8325)$ & $0.68(0.6176)$ & $3.4(0.2999)$ & $26.55(0.0000)$ & $2.89(0.0585)$ \\
\hline
\end{tabular}

Means followed by same letter significantly different at $1 \%$ or $5 \%$ level of significance

\section{Effect of Substrates on Biological and Economic Yield (Kg)}

The Average weight of individual fruiting body was statistically similar for all treatments. The Mean Biological yield varied statistically between treatments ranging from 0.23-0.47, with T5 (0.47) having the highest mean Biological yield, while T3 (0.29) had the lowest. The mean economic yield on the other hand was highest in T1 (0.43) and T5 (0.41) but lowest in T3 (0.28) as shown in Table 4 and Figure 2. Pictures of some of the cultivated mushrooms are shown Figure $3 \mathrm{~A}$ and $\mathrm{B}$.

Table 4 Effect of Substrates on Biological and Economic Yield

\begin{tabular}{|c|c|c|c|c|c|}
\hline Treatments & $\begin{array}{l}\text { Mean Fresh } \\
\text { weight (kg) }\end{array}$ & $\begin{array}{l}\text { Mean Dry } \\
\text { weight (kg) }\end{array}$ & $\begin{array}{l}\text { Average } \\
\text { weight of } \\
\text { individual } \\
\text { fruiting body }\end{array}$ & $\begin{array}{l}\text { Mean } \\
\text { Biological } \\
\text { yield }\end{array}$ & $\begin{array}{l}\text { Mean } \\
\text { Economic } \\
\text { yield }\end{array}$ \\
\hline \multicolumn{6}{|l|}{ Corn cobs_corn flour } \\
\hline $\mathrm{T} 1$ & $0.45 \pm 0.00^{\mathrm{b}}$ & $0.08 \pm 0.00^{\mathrm{ab}}$ & $0.01 \pm 0.00^{\mathrm{a}}$ & $0.45 \pm 0.00 \mathrm{~b}$ & $0.43 \pm 0.01 b$ \\
\hline Iroko_corn flour T3 & $0.29 \pm 0.04^{\mathrm{a}}$ & $0.06 \pm 0.01^{\mathrm{a}}$ & $0.01 \pm 0.00^{\mathrm{a}}$ & $0.29 \pm 0.04^{\mathrm{a}}$ & $0.28 \pm 0.03^{\mathrm{a}}$ \\
\hline Iroko_rice bran T4 & $0.37 \pm 0.06 \mathrm{a}^{\mathrm{b}}$ & $0.07 \pm 0.01^{\mathrm{ab}}$ & $0.01 \pm 0.00^{\mathrm{a}}$ & $0.37 \pm 0.06^{\mathrm{ab}}$ & $0.35 \pm 0.06^{\mathrm{ab}}$ \\
\hline \multicolumn{6}{|l|}{ Eucalyptus_corn flour } \\
\hline & $0.47 \pm 0.14^{\mathrm{b}}$ & $0.09 \pm 0.03^{\mathrm{b}}$ & $0.02 \pm 0.01^{\mathrm{a}}$ & $0.47 \pm 0.16^{\mathrm{ab}}$ & $0.41 \pm 0.15^{\mathrm{ab}}$ \\
\hline Eucalyptus_rice bran & & & & & \\
\hline T6 & $0.36 \pm 0.11^{\mathrm{ab}}$ & $0.07 \pm 0.02^{\mathrm{ab}}$ & $0.01 \pm 0.01^{\mathrm{a}}$ & $0.36 \pm 0.11^{\mathrm{ab}}$ & $0.35 \pm 0.11^{\mathrm{ab}}$ \\
\hline$F(p)$ & $2.81(0.0634)$ & $2.24(0.1133)$ & $0.93(0.4702)$ & $1.67(0.2090)$ & $1.73(0.1957)$ \\
\hline
\end{tabular}

Means followed by same letter significantly different at $1 \%$ or $5 \%$ level of significance

\section{Correlation analysis}

A significant and positive correlation between economic yield and fresh weight was observed with the differently supplemented substrates (Fig.4). This suggests that economic yield dependent on fresh weight. The $\mathrm{R}^{2}$ value indicated that $92 \%$ of economic yield of oyster mushroom ( $P$. ostreatus) was attributed to the fresh weight of fruiting body.

\section{Discussion}

The highest time from stimulation to primordia initiation differed with the findings of Ahmed (1998) who found out that Pleurotus ostreatus took 23-27 days for initiation of fruiting bodies, unlike Yoshida et al. (1993) reported that the number of fruiting bodies was lower, but increased when the substrates were mixed with different supplements. Bhuyan (2008) in a same type of experiment on the effects of substrates on the yields of cultivated mushroom, found similar results. 


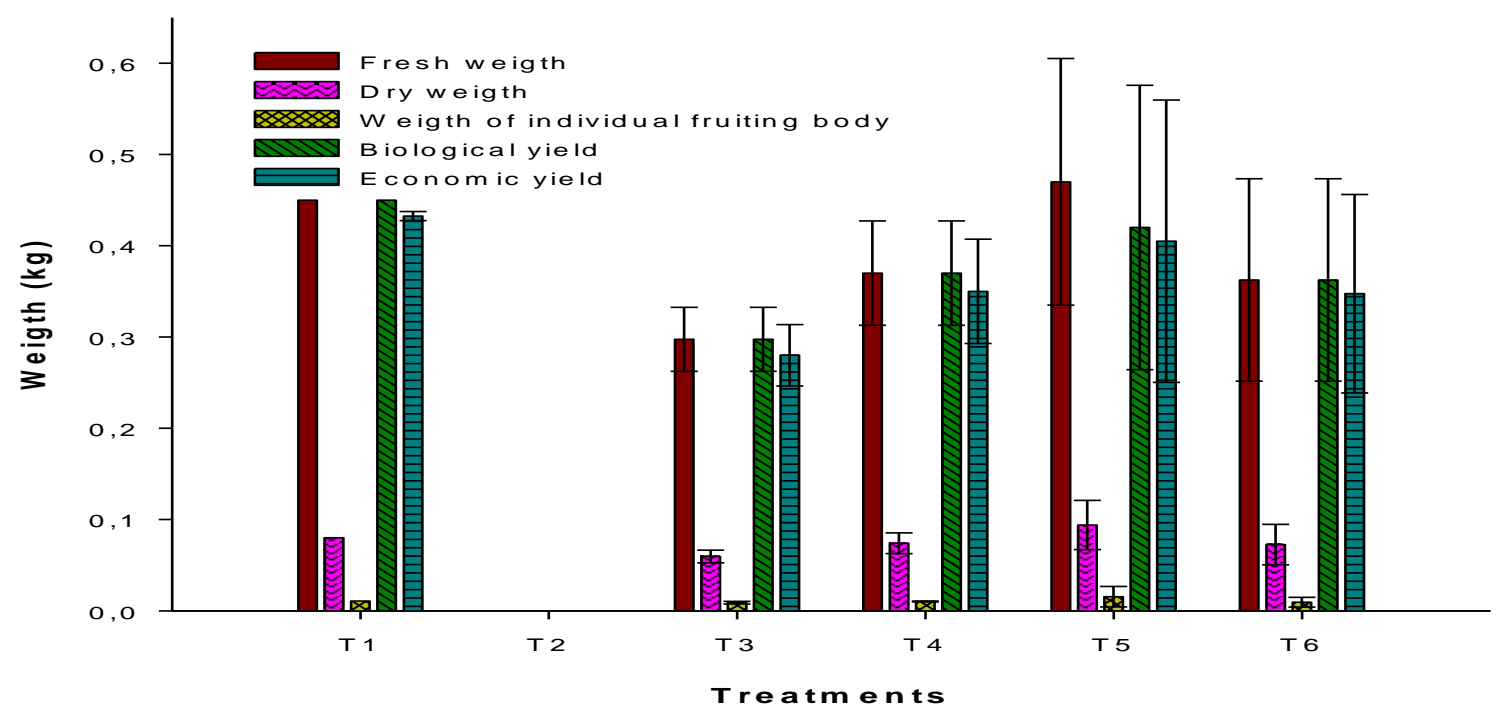

Fig. 2 - Effect of Different Substrates on Yield
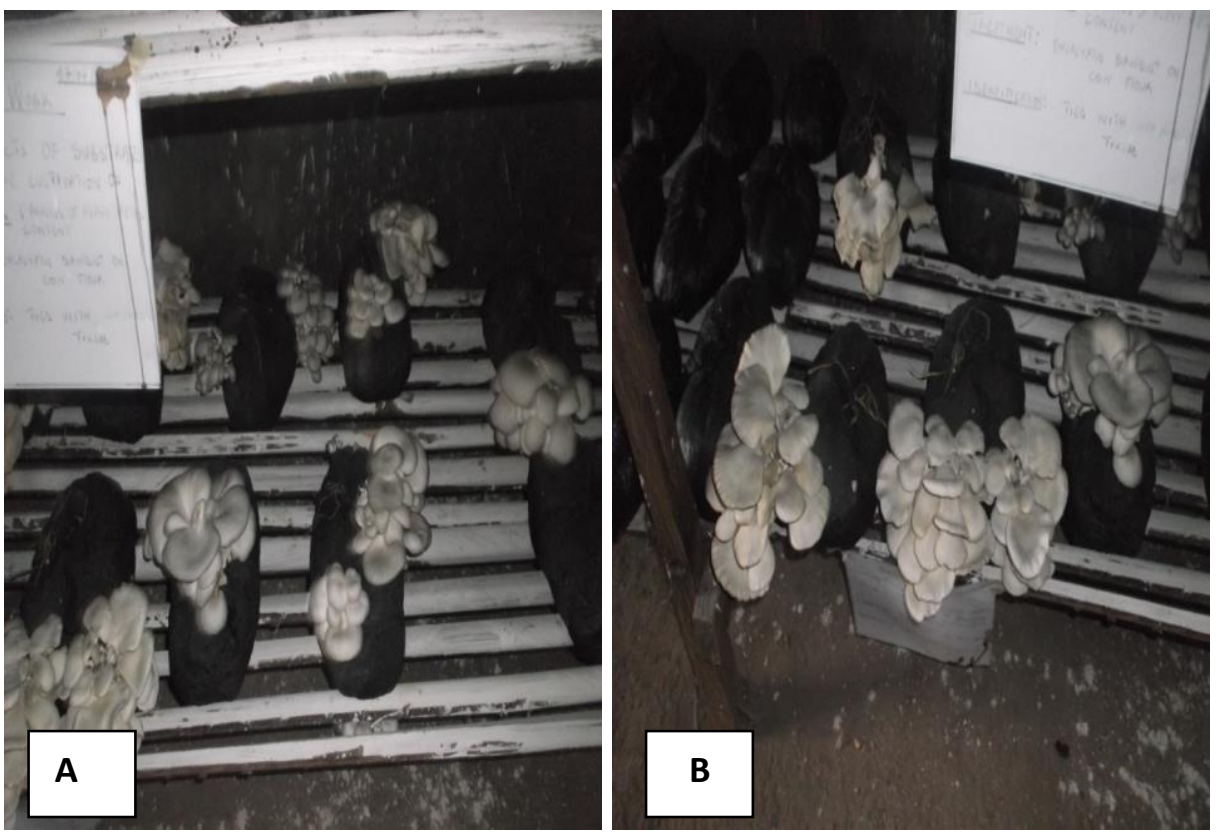

Fig. 3 - AB - Fruiting bodies of $\mathrm{T}_{5}$ and $\mathrm{T}_{6}$ respectively

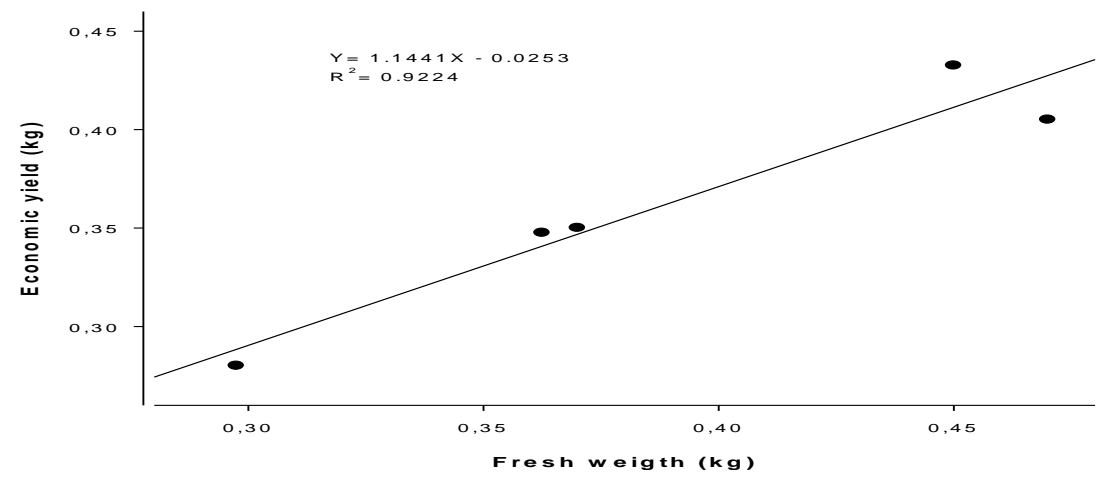

Fig. 4 - Functional Relationship between Economic and Fresh Weight as influenced by substrates 
The results varied with the findings of Sarker et al.(2007) and Habib (2005), who reported that the stipe length of Pleurotus spp. on different substrate varied from 1.93-2.97cmand the diameter ranged from $0.74-1.05 \mathrm{~cm}$. The difference among the findings may be due to the difference in substrates and supplements used or the species varieties. The humidity of the bags in which mushrooms were cultivated was favourable, since this fungus was grown in late March and early April when the coming rains are abundant in this part of the country. The thickening of the mycelia in the bags, colonization of the bags was an indication for the bags to be opened for fruiting.

The result of the present study on the effect of substrates on biological and economic yield corroborates with Amin et al. (2007) who found the highest biological yield of $0.24 \mathrm{~kg} / \mathrm{packet}$. He also found that the trend of economic yield corresponded with different supplements at different level. Payapanon et al. (1994) mentioned that suitable amount of supplements added to rice straw medium maximized economic yield of oyster mushroom at optimum production cost. For correlation study the strong association is due to the fact that; the higher the fresh weight, the larger the amounts of mushroom material for sale (economic yield) as these mushrooms are sold in kilograms when freshly harvested.

Eucalyptus on corn flour (T5) showed the best performance compared to other substrates used for the cultivation of Pleurotus ostreatus in terms of growth and yield parameters measured. It was followed by; corn cobs on corn flour (T1), eucalyptus on rice bran (T6), iroko on rice bran (T4), iroko on corn flour (T3), and finally corn cobs on rice bran (T2), which did not sprout due to one hundred percent contamination by brownish fungal growth, known as the Trichoderma disease of mushroom. High yields and absence of contamination risks with T5, makes it the most appropriate substrate for the cultivation of the oyster mushroom. Also, despite the $75 \%$ contamination in T1 it could also be one of the most appropriate substrate for cultivation provided that the Trichoderma disease of mushroom is controlled and care is taking to eliminate or minimize contamination. Eucalyptus sawdust and corn flour are relatively abundant in rural communities in the study area where resource poor farmers reside and it can therefore be used to cultivate Pleurotus ostreatus, providing a highly profitable agribusiness that produces not only nutritious and medicinal food products from different substrates, but also helps to dispose them in the environment in a friendly manner and conserving mushroom biodiversity in the forest.

\section{Acknowledgements}

This work was financed by the Research Modernization Grant from the Ministry of Higher Education, Cameroon. The management of Mbeng-Adio Mushroom cultivation center, Banjah Bamenda is thanked for use of facilities.

\section{References}

Ahmed S. 1998 - Development of mushroom varieties suitable for rural level in Bangladesh. Report presented in BARC Annual Review Programme.pp.273.

Ajonina AS, Tatah LE. 2012 - Growth performance and yield of oyster mushroom (Pleurotus ostreatus) on different substrates composition in Buea South West Cameroon. Science Journal of Biochemistry 10, 1-6, DOI: 10.7237/sjbch/139.

Amin SMR, Rahman MM, Hossain MM, Haque MM, Sarker NC. 2007 - Effect of Different Substrates on the Growth and Yield of Five Selected Oyster Mushrooms. Bangladesh journal of Mushroom $1(2), 21-25$.

Atri NS, Lata. 2013 - Studies for culturing and cultivation of Lentinus cladopus Lév., Mycosphere 4 (4): 675-682.

Beetz A, Kustida M. 2004 - Mushroom Cultivation and Marketing. ATTRA Publication \# IP 087, Retrieved from: http://attra.ncat.org/attrapub/mushroom.html.

Bhattacharjya DK, Ratan KP, Nuruddin M, Ahmed KU. 2014 - Effect of Different Saw Dust Substrates on the Growth and Yield of Oyster Mushroom (Pleurotus ostreatus), Journal of Agriculture and Veterinary Science 7 (2), 38-46. 
Bhuyan MHMB. 2008 - Study on Preparation of Low Cost Spawn Packets for the Production of Oyster Mushroom (Pleurotus ostreatus) and its Proximate Analysis, M.S. Thesis, Department of Biochemistry, SAU, Dhaka. pp149.

Bonginkhosi E, Diana M, Michael TM. 2012 - Growth and Yield Response of Oyster Mushroom (Pleurotus ostreatus) Grown on Different Locally Available Substrates. Journal of Biological Sciences 4(5), 623-629.

Degrande A, Asaah E, Tchoundjeu Z ,Kanmegne J, Duguma B, Franzel S.2007 - Opportunities and constraints to adoption of improved fallows: ICRAF's experience in the humid tropics of Cameroon', in: A. Bationo, B. Waswa, J. Kihara, J. Kimetu (eds), Advances in Integrated Soil Fertility Management in Sub-Saharan Africa: Challenges and Opportunities, Springer, The Netherlands, ISBN:978-1-4020-5759-5.

Douanla-Meli C. 2007 - Fungi of Cameroon: ecological diversity with emphasis on the taxonomy of non-gilled Hymenomycetes from the Mbalmayo Forest Reserves. Bibliotheca Mycologica, pp410.

Ediriweera SS, Wijesundera RLC, Nanayakkara CM, Weerasena OVDSJ. 2015 - Comparative study of growth and yield of edible mushrooms, Schizophyllum commune Fr., Auricularia polytricha (Mont.) Sacc. and Lentinus squarrosulus Mont. on lignocellulosic substrates. Mycosphere 6 (6), 760-765.

Egbe EA, Kinge TR, Tabi EM, Nji TM, Mih AM. 2013 - Diversity and distribution of macro fungi (mushrooms) in the Mount Cameroon Region. Journal of Ecology and the Natural Environment 5, 318-334.

Gomez KA, Gomez AA. 1984 - Statistical procedure for Agricultural research. 2nd edition. John Wiley and Sons, New York. pp680.

Habib MA. 2005 - Comperative study on cultivation and yield Performance of Oyster Mushroom (Pleurotus ostreatus) on different substrates, M. S. Thesis, Department of Biotechnology, BAU, Mymensingh. pp137.

Kinge TR, Nji TM, Ndam LM, Mih AM. 2014 - Mushroom research, production and marketing in Cameroon: A review, Issues in Biological Sciences and Pharmaceutical Research 2 (7), 069074.

Li Y. 2012 - Present development situation and tendency of edible mushroom industry in China. Mushroom Science 18, 3-9.

Lourdes AT, Arvin SMA, Jerremy BR. 2008 - Agronomic Responses of Oyster Mushroom (Pleurotus ostreatus.) on Different Agricultural Wastes as Substrates. Retrieved from: http://region1. dost. gov.ph/IPSF \% 20compilations/pdf\%20files/agronomic \% 20responses.

Nicholas LG, Kerry O. 2006 - Psilocybin Mushroom Handbook- easy indoor and outdoor cultivation. ISBN 13 publishing co Pvt Ltd: pp.649.

Pathmashini L, Arulnandhy RS, Wilson W. 2008 - Cultivation of Oyster Mushroom (Pleurotus ostreatus) on Sawdust.Journal of Biological Sciences 37(2), 177-182.

Payapanon A., Punnee B, Poungpaka SNA. 1994 - Optimum amount of the rice bran for Oyster mushroom (Pleurotus florida) cultivation. Kasetsart University, Bangkok (Thailand). Proceedings of the 24th National Conference: Poster Session. Bangkok. pp. 259-264.

Sarker NC, Hossain MM,Sultana N,MianH, Amin SR. 2007 - Performance of Different Substrates on the Growth and Yield of Pleurotus ostreatus (Jacquin ex Fr.) Kummer. Bangladesh Journal of Mushroom1 (2), 9-20.

Thawthong A, Karunarathna SC, Thongklang N, Chukeatirote E, Kakumyan P, Chamyuang S, Rizal LM, Mortimer PE, Xu J, Callac P, Hyde KD. 2014 - Discovering and Domesticating Wild Tropical Cultivatable Mushrooms, Chiang Mai Journal of Science 41(4), 731-764.

Wang HX, Liu WK, Ooi VE, Chang ST. 1996 - A polysaccharide-peptide complex from cultured mycelia of the mushroom Tricholoma mongolicum with immunoenhancing and antitumour activities. International Journal of Biochemistry and Cell Biology 74(1), 95-100.

Yoshida N, Takahashi N, Nagao T. 1993 - Effect of edible mushroom (Pleurotus ostreatus) cultivation on in vitro digestibility of wheat straw and sawdust substrate. Journal of Japanese Society of Grassland Science39 (2), 177-182. 